\title{
SCREENING POTENTIAL ANTIOXIDANT AND ANTIBACTERIAL ACTIVITIES OF PROTEIN HYDROLYSATES DERIVED FROM GERMINATED LABLAB BEAN, PIGEON PEA AND KIDNEY BEAN
}

\author{
Ketut Ratnayani ${ }^{1}$, Indriani Wisnu Susanto Panjaitan ${ }^{1}$, and Ni Made Puspawati ${ }^{1}$ \\ ${ }^{1}$ Chemistry Department, Faculty of Natural Sciences, Udayana University \\ Bali, Indonesia \\ Email : ratnayaninew@gmail.com
}

\begin{abstract}
Protein hydrolysate contains a mixture of various lengths of short peptides chain and free amino acids that may excert biological activities. This research aims to screen potential antioxidant and antibacterial activities of protein hydrolysate produced from three kinds of germinated beans i.e. lablab bean (Lablab purpureus), pigeon pea (Cajanus cajan (L.) Millsp) and kidney bean (Phaseolus vulgaris) through enzymatic hydrolysis process. The steps of research included germination process of the beans prior to total protein isolation, enzymatic hydrolysis of total protein isolates using pancreatin enzyme, evaluation of in vitro antioxidant activity of the hydrolysates protein using DPPH (1,1-diphenyl-2-picryl hydrazyl) method, and antibaterial activity testing towards Eschericia coli and Staphyllococcus aureus bacteria. The results revealed that pancreatine enzyme was able to hydrolyse germinated protein of lablab bean, pigeon pea and kidney bean at the experiment condition applied with degree of hydrolysis $34.12 \%, 27.44 \%$, and $30,93 \%$ respectively. It was also found that protein hydrolysates of lablab bean, pigeon pea, and kidney bean demonstrated antioxidant activity which percentage radical DPPH scavenging activity of $84.02 \%$, $68.97 \%$ and $67.89 \%$. On the other hand, all of those protein hydrolysates did not show any antibacterial activity towards Eschericia coli and Staphyllococcus aureus bacteria.
\end{abstract}

Keywords - antioxidant, protein hydrolysate, germination, pigeon pea, lablab bean, kidney bean.

\section{INTRODUCTION}

Protein hydrolysates can be produced by in vitro enzymatic hydrolysis or fermentation of protein. The protein hydrolysates contain a mixture of various types of short chain peptides and free amino acids. The sequence types of peptides and free amino acids resulting from protein hydrolysis depends on the degree of hydrolysis, which is influenced by substrate concentration, enzyme concentration, $\mathrm{pH}$ value, time, and temperature used in the process.

In general, the protein hydrolysates will improve the characteristics of various food products, as a flavor enhancer and theurapetic healing. Protein hydrolysates can also be choosen as a menu for people with indigestion problem. In addition, protein hydrolysates containing mixtures of short chain peptides which vary in the type, number and sequence of amino acids usually excert specific physiological effects to living organisms which are known as bioactive peptides. In the last two decades, peptides resulting from partial enzymatic hydrolysis (protein hydrolysate) of protein food has been of concern to the food experts, because the peptides have biological activity such as antioxidant, antibacterial, and antihypertention that are important to improve human health. Bioactivities of these peptides are determined primarily by the composition and sequence of its amino acid (1).

Nowadays, legume beans have been used not only as a source of protein for growth, but have also become a source of bioactive compounds such as bioactive peptides, which are beneficial for human health. Lunasin and BBI (Bowman-Birk Inhibitor) are examples of bioactive peptides derived from soy that have been proven to be effective as a suppressor agent carcinogenesis in vitro and in vivo in a model system (2). Nisin is one of the wellknown antibacterial bioactive peptides that have been approved by the FDA as a food grade preservative. 
Legume beans generally contain $20-25 \%$ protein which is 2-3 times higher than cereals. Soybeans are one type of legume that has been studied extensively for its protein hydrolysates and its bioactive peptides component.Therefore, it is necessary to do research to explore other types of beans that also contain high protein content with specific protein sources that may produce potentially biological active protein hydrolysates. Pigeon pea (Cajanus cajan. (L) mill sp), kidney bean (Phaseolus vulgaris. $L$ ) and lablab bean (Lablab purpureus) are very popular as sources of food proteins in Indonesia, but little has been known for their bioactive peptides.

Germination is one of the pretreatment methods used prior to enzymatic hydrolysis of protein. It can cause significant changes in biochemical characteristics of bean. During the proses, the storage proteins can be degraded by endogenous protease that is activated in the germination phase. This can increase the nutritional value, because it can improve the digestibility of protein, decrease the antinutritional factors and hydrolyze oligosaccharides (3). Sefatie et al in 2008, found that the germination process can increase the activity of antioxidant in black soybean (Glycine max L.) protein hydrolysates (4).

Based on this background, this research aims to screen the potential antioxidant and antibacterial activities of germinated protein flour of lablab bean, pigean pea, and kidney bean.

\section{METHODS AND PROCEDURES}

\section{A. Beans germination process}

Beans were sorted, washed with water, soaked in $50{ }^{\circ} \mathrm{C}$ warm water with ratio beans to water (1:3) and then allowed to stand at room temperature for 12 hours. Once soaked, beans were drained and placed in perforated containers (baskets) coated with banana leaves to keep humidity and avoid stagnant water in the container. The beans were then germinated for 30 hours in a container and sprayed with water twice a day to maintain moisture. Sprouts were then dried in the oven at $50^{\circ} \mathrm{C}$ for 24 hours. Dried sprouts then blended and sieved using a sieve size of 60 mesh to yield germinated beans flour. The flour was defatted by maceration using $n$-hexane (1:5) for 10 hours at room temperature.

\section{B. Protein isolation of bean sprouts}

At this stage, germinated beans flour was mixed with distilled water with a ratio $(1: 10)$ at $60{ }^{\circ} \mathrm{C}$ subsequently extracted at $\mathrm{pH} 8.5$ to 8.7 by the addition of $2 \mathrm{~N} \mathrm{NaOH}$ at $60{ }^{\circ} \mathrm{C}$ for 30 minutes. After that, the mixture was centrifuged at $2000 \mathrm{x}$ g for 15 minutes, the supernatant obtained was collected as protein fraction. Furthermore, the acidic extraction stage was done to the supernatant at $\mathrm{pH}$ 4.5 with the addition of $2 \mathrm{~N} \mathrm{HCl}$. Then centrifuged at $2000 \mathrm{x}$ $\mathrm{g}$ for 15 minutes, took the pellet and dried at a temperature of $50{ }^{\circ} \mathrm{C}$ for 12 hours.

\section{Enzymatic hydrolysis of sprout protein}

Protein solution was made by mixing protein isolate with distilled water with ratio protein : water $(1: 5) \mathrm{w} / \mathrm{w}, 2 \%$ of pancreatin enzyme was then added and the $\mathrm{pH}$ was adjusted to $\mathrm{pH} 7.0$ by adding $0.1 \mathrm{M} \mathrm{NaOH}$ or $0.1 \mathrm{M} \mathrm{HCl}$. Subsequently the mixture was incubated at $37{ }^{\circ} \mathrm{C}$ for 30 minutes. The activity of pancreatin enzyme was terminated by heating at $95{ }^{\circ} \mathrm{C}$ for 15 minutes, then the mixture was centrifuged at $4000 \mathrm{x} \mathrm{g}$ for 10 minutes. After cold, the supernatant was collected and stored at $-20^{\circ} \mathrm{C}$.

\section{Determination of Degree of Hydrolysis $(\% D H)$}

A total of $10 \mathrm{~mL}$ of protein hydrolysates were mixed with $10 \mathrm{~mL}$ of $20 \%$ TCA to acquire $10 \%$ of soluble nitrogen, and then centrifuged at $2600 \mathrm{x} \mathrm{g}$ for 15 minutes. The supernatant was decanted and the levels of nitrogen was analyzed by the Kjeldahl method. The degree of hydrolysis $(\% \mathrm{DH})$ can be calculated as follows :

$$
\% \text { DH }=\frac{(N \text { dissolve in } 10 \% T C A) /(N \text { total in the sample })}{N \text { dissolve in } 10 \% T C A} \times 100 \%
$$

$500 \mathrm{~mL}$ of sample solution (protein hydrolysate) was mixed with $500 \mathrm{~mL}$ of $99.5 \%$ ethanol and $125 \mathrm{~mL}$ of $99.5 \%$ ethanol containing $0.02 \%(w / v) \quad 2,2$-diphenyl-1picrylhydrazyl (DPPH). The mixture was kept in the dark at room temperature for 60 minutes and the absorbance of sample was measured by spectrophotometer at $\lambda 517 \mathrm{~nm}$.

$\%$ Radical scavenging $=\frac{\text { Acontrol }+ \text { A blanko }- \text { A sample }}{\text { A control }} \times 100 \%$

\section{RESULTS AND DISCUSSION}

The degree of hydrolysis as summarised in Table 1 represents the ability of pancreatin enzyme to hydrolyse germinated protein of lablab bean, pigeon pea, and kidney bean.

TABLE 1

DEGREE OF HYDROLYSIS OF GERMINATED BEANS PROTEIN HYDROLYSATES

\begin{tabular}{ccc}
\hline \hline No & Sample & Degree of Hydrolysis \\
\hline 1 & Pigeon Pea Protein Hydrolysates & $27.44 \%$ \\
2 & Kidney Bean Protein Hydrolysates & $30.93 \%$ \\
3 & Lablab Bean Protein Hydrolysates & $34.12 \%$ \\
& \\
\hline \hline
\end{tabular}

The antioxidant activity of protein hydrolysates from germinated beans of lablab bean, pigeon pea and kidney bean was depicted in Table 2 as the percentage scavenging of radical DPPH.

TABLE 2

THE ANTIOXIDANT ACTIVITY OF PROTEIN HYDROLYSATES PRODUCED FROM LABLAB BEAN, PIGEON PEA, AND KIDNEY BEAN

\begin{tabular}{clc}
\hline \hline No & \multicolumn{1}{c}{ Sample } & $\begin{array}{c}\text { Percentage } \\
\text { Radical Scavenging }\end{array}$ \\
\hline 1 & Pigeon Pea Protein Hydrolysates & $68.97 \%$ \\
2 & Lablab Bean Protein Hydrolysates & $84.02 \%$ \\
3 & Common Bean Protein Hydrolysates & $67.89 \%$ \\
& \\
\hline \hline
\end{tabular}


The result of antibacterial activity assay of protein hydrolysate obtained from germinated of lablab bean, pigeon pea and kidney bean was tabulated in Table 3.

TABLE 3

THE RESULT OF ANTIBACTERIAL ASSAY OF BEAN SPROUT PROTEIN HYDROLYZATE

\begin{tabular}{|c|c|c|}
\hline Sample & $\begin{array}{l}\text { Escherecia } \\
\text { coli }\end{array}$ & $\begin{array}{l}\text { Staphylococcus } \\
\text { aureus }\end{array}$ \\
\hline Pigeon Pea Protein Hydrolszate & Negative & Negative \\
\hline $\begin{array}{l}\text { Lablab Bean Protein } \\
\text { Hydrolysate }\end{array}$ & Negative & Negative \\
\hline $\begin{array}{l}\text { Common Bean Protein } \\
\text { Hydrolysate }\end{array}$ & Negative & Negative \\
\hline
\end{tabular}

In this research, a combination of germination and enzymatic hydrolysis of protein were performed to produce protein hydrolysates derived from lablab bean, pigeon pea and kidney bean which may contain fragments of short chain peptides that elicited biological activity. Germination process was done prior to enzymatic hydrolysis of the beans to reduce non-nutraceutical compounds present in the beans such as lectin, pytic acid and tripsin inhibitor and to improve the nutritional quality of protein by increasing their digestibility since the germination process produced less complex peptide compounds or shorter chain of peptides. During the germination process, the storage protein was degraded to produce new proteins that fit the needs of growing into a new plant. The degradation process is started when there is contact between the endogenous protease in seeds with water and penetrate the cells of seeds during imbibition process which is done by soaking the seeds using warm water $\left(50^{\circ} \mathrm{C}\right)$ and allowed to stand at room temperature for 30 hours. The formation of the protein with a smaller size (shorter chain of peptides) during germination will give advantage to the easier process of pancreatin enzymatic process of hydrolysis to produce the protein hydrolysate derived from lablab bean, pigeon pea, and kidney bean. This is because the existence of a concept which assumes that the smaller size of protein molecules will simplify and improve the efficiency of contact between the protein substrate with the active site of protease enzyme that acts as a catalyst.

The enzymatic reactions are mainly influenced by several factors such as $\mathrm{pH}$, temperature, the ratio of the enzyme to the substrate, time of hydrolysis, types of substrate, types of enzymes, the presence of inhibitors and others. In this research, conditions applied for enzymatic pancreatin hydrolysis was a protein substrate ratio:water (1:5) $\mathrm{w} / \mathrm{w}$, pancreatin enzyme $2 \%, \mathrm{pH} 7.0$, temperature of $37^{\circ} \mathrm{C}$ and 30 minutes.

The degree of hydrolysis (DH) is quantitatively analysis to determine how far that pancreatin enzyme hydrolysis has been run. The degree of hydrolysis can be defined as the percentage of peptide bonds that have been hydrolyzed. DH can be calculated by determining the amount of the amine group recently released. Based on the calculation, the DH results can be seen in Table 3.1. It can be concluded that the protein hydrolysates of lablab bean sprouts has the highest $\mathrm{DH}$, reaching $34.12 \%$, which indicates that the pancreatin enzyme's ability to hydrolyze proteins in lablab bean sprouts (at the hydrolysis conditions applied) most effective than other types of bean protein. The different value of DH obtained for each beans maybe due to the different types of substrate protein because the enzymes activity is affected by the type of substrate used $(\mathrm{Km}$ value). The big difference in the value of the $\mathrm{DH}$ affects to the functional properties and biological activity of the protein hydrolysates product.

Some protein hydrolysate have been proved to exert antioxidant activity. The antioxidant activity of bioactive peptides may influence by their amino acids content. Some amino acids have been examined as having antioxidant activity, such as aromatic amino acid (tryptophan, tyrosine, phenylalanine), amino acid with indole and imidazole functional groups. The phenolic functional groups present in these types of amino acids can act as a proton donor for electron-deficient radical and efficiently catch the electron [1].

Nisin is one example of bioactive peptides known to have antimicrobial activity as bacteriocin and it has been used as a natural food preservative. Hence, protein hydrolysates derived from lablab bean, pigeon pea, and kidney bean are expected to have antibacterial activity. However, protein hydrolysates obtained from pancreatin hydrolysis of germinated protein lablab bean, pigeon pea, and kidney bean does not show any antibacterial activities towards Eschericia coli and Staphylococcus aureus bacteria. This result indicated that protein hydrolysates from this three beans are inactive due to the protein hydrolysate are still in mixtures of different types peptides which differ in types of amino acids, size, and sequent or they are not contained bioactive peptides which has specific amino acids, size and sequent for antibacterial activity. It was reported that kidney beans have been known to produce antifungal bioactive peptides called vulgarinin, while in soybeans, bioactive peptides derived from soy tempeh having molecular weight of $<3$ kiloDalton exhibit antibacterial activities (6). As it is reported by Hayes 2006, sodium caseinates fermented with Lactobacillus achidophilus showed no antimicrobial activity in its protein hydrolysate form but after fractionation it showed antibacterial activity.This result suggested fractionation and purification of protein hydrolysates by size and charge increase their antimicrobial activity. Electrostatic interactions between the charged peptides have unfavorable influence on the activity. Fractionation and purification will reduce the interaction between different peptides so it can improve their antimicrobial activity (7). Therefore, further study needs to be done to fractionate and purify peptides mixtures present in protein hydrolysates of lablab beans, pigeon pea, and kidney bean to give peptides with certain size or pure peptides which may have antibacterial activities or other biological activities.

\section{CONCLUSION}

Pancreatin enzyme is able to hydrolyse protein of germinated Lablab bean, Kidney bean, and Pigeon pea where the degree of hydrolysis is $34.12 \%, 30.93 \%$, and 
27.44\% respectively. Protein hydrolysates derived from germinated lablab bean demonstrated the highest antioxidant activity with percentage to scavenge $84.02 \%$ of radical DPPH followed by kidney beans $68.97 \%$ and pigeon pea $67.89 \%$. On the other hand, none of these protein hydrolysates showed any antibacterial activity towards Escherichia coli and Staphyllococcus aureus bacteria.

\section{ACKNOWLEDGMENT}

We thank LPPM UNUD for research grants through DIPA Udayana University in accordance with the Employment Agreement Implementation Leading Research Activities Grant Program No: 2749 / UN14.1.28 / LT / 2016 dated June 27, 2016.

\section{REFERENCES}

[1] Castro, R.J.S., dan Sato, H.H. 2015. Review : Biologically Active Peptides: Processes for Their Generation, Purification and Identification and Applications as Natural Additives in the Food and
Pharmaceutical Industries. Food Research International.74: 185198.

[2] Malaguti, M., G. Dinelli, E. Leoncini, V. Bregola, S. Bosi, A.F.G. Cicero, and S. Hrelia. 2014. Review: Bioactive Peptides in Cereals and Legumes: Agronomical, Biochemical and Clinical Aspects. Int. J. Mol. Sci. 15. : 21120-21135. www. mdpi.com/journal/ijms.

[3] Bau, H.M, Villaume, C., dan Mejean, L., 2000. Effects of Soybean (Glycine max) Germination on Biologically Active Components, Nutritional Values of Seeds and Biological Characteristics. Nahrung/Food. 44: 2-6.

[4] Sefatie, R.S., T. Fatoumata, K. Eric, H.S. Yong, and L. Guo-wei. 2013. In vitro Antioxidant Activities of Protein Hydrolysate from Germinated Black Soybean (Glycine max L.) Adv. J. Food Sci. Technol. 5(4): 453-459.

[5] Bersuder, P., M. Hole, G. Smith. 1998. Antioxidants from a Heated Histidineglucose Model System I: Investigation of the Antioxidant Role of Histidine and Isolation of Antioxidants by High Performance Liquid Chromatography. J A Oil Chem Soc. 75:181-187.

[6] Roubus-van den HPJ, Dalmas E, Nout MJR, Abee T. 2010. Soya Bean Tempe Extracts Show Antibacterial Activity Against Bacillus cereus Cells and Spores. J Appl Microbiol 109 : 137-145. DOI : 10.1111/j.1365-2672.2009.04637.x.

[7] Hayes M, Ross RP, Fitzgerald GF, Hill C, Stanton C. 2006. Caseinderived Antimicrobial Peptides Generated by Lactobacillus acidophilus DPC6026. Appl Environ Microbiol. 72:2260-2264. 